\title{
Perilaku caring perawat terhadap kepuasan pasien di UPT Puskesmas rawat inap
}

\author{
Triyoso ${ }^{1 *}$, Martina Sari ${ }^{2}$ \\ 1Program DIII Keperawatan Fakultas Kedokteran Universitas Malahayati. *Email: triyosoalip@gmail.com \\ 2UPT Puskesmas Rawat Inap Bukit Kemuning Kabupaten Lampung Utara. Email: martinasari1983@gmail.com
}

\author{
Abstract \\ Nurse caring behaviors and patient satisfaction: The impact of patients experience \\ at Bukit Kemuning inpatient public health centre
}

Background: The results of the pre-survey conducted on January - 2019 based on the medical records of the Bukit Kemuning Inpatient Health Center in North Lampung recorded in 2018 had of 279 inpatients. Base on evaluation in Bukit Kemuning Inpatient Health Center, the Minimum Service Standards (MSS) achievement scored of $67.29 \%$ describes the service quality is still suboptimal.

Purpose: Knowing relationship between nurses' caring behavior towards patient satisfaction in Bukit Kemuning Inpatient Health Centre North Lampung Regency

Method: A quantitative cross-sectional approach, the population of all outpatient who had experienced hospitalization at Bukit Kemuning Inpatient Health Center, with a sample of 282 respondent. The variables of this study were nurse caring behavior and patient satisfaction. The research conducted at the Bukit Kemuning Inpatient Health Center UPT North Lampung Regency. data collection using a questionnaire. Data analysis was univariate and bivariate (chi square).

Results: Knowing the respondents' statement that nurses' shown caring behavior in a poor category of 162 $(57.4 \%)$, patients unsatisfied of $140(49.4 \%)$, There is a relationship between Nurse caring behaviors and patient satisfaction at Bukit Kemuning inpatient public health centre North Lampung Regency ( $p$-value $=0.000 \mathrm{OR}=$ 4.659)

Conclusion: There is a correlation between Nurse caring behaviors and patient satisfaction: The impact of patients experience

at Bukit Kemuning inpatient public health centre, for the Health Center management to consider for nurses' staff for conducting caring behavior training and improve health services.

\section{Keywords: Nurses; Caring behavior; Patient; Satisfaction}

Pendahuluan: Standar kepuasan pasien di pelayanan kesehatan ditetapkan secara nasional oleh Departemen Kesehatan. Hasil pra survey yang dilakukan tanggal 5 - 9 Januari 2019 berdasarkan data rekam medis Puskesmas Rawat Inap Bukit Kemuning Kabupaten Lampung Utara tercatat tahun 2018 jumlah pasien yang melakukan kunjungan rawat jalan sebesar 11.169 orang dan rawat inap sebanyak 279 orang. Puskesmas Rawat Inap Bukit Kemuning Kabupaten Lampung Utara Standar SPM > 90 \% dengan hasil capaian hanya 67, 29\% sehingga dapat menggambarkan mutu pelayanan masih belum optimal.

Tujuan : Diketahui hubungan perilaku caring perawat terhadap kepuasan pasien di UPT Puskesmas Rawat Inap Bukit Kemuning Kabupaten Lampung Utara tahun 2019

Metode: Penelitian kuantitatif pendekatan Cross Sectional, populasi seluruh pengunjung Puskesmas, dengan sampel berjumlah 282 orang Objek dalam penelitian ini adalah perilaku caring perawat dan kepuasan pasien. Penelitian dilakukan di UPT Puskesmas Rawat Inap Bukit Kemuning Kabupaten Lampung Utara. bulan Januari Juni 2019 . pengumpulan data menggunakan kuesioner. Analisis data secara univariat dan bivariat (chi square). Hasil: Diketahui pernyataan responden tentang perawat yang menunjukkan perilaku caring kategori buruk, sebesar $162(57,4 \%)$ responden, kepuasan keluarga pasien kurang puas, sebesar $140(49,4 \%)$ responden, Ada hubungan antara perilaku caring perawat terhadap tingkat kepuasan keluarga pasien di UPT Puskesmas Rawat Inap Bukit Kemuning Kabupaten Lampung Utara tahun 2019 ( $p$-value $=0,000,0,05,0 R=4,659$ ) 
Simpulan: Ada hubungan antara perilaku caring perawat terhadap tingkat kepuasan keluarga pasien di UPT Puskesmas Rawat Inap Bukit Kemuning Kabupaten Lampung Utara tahun 2019, bagi pihak manajemen Puskesmas sebagai bahan pertimbangan untuk mengadakan pelatihan perilaku caring perawat guna meningkatkan pelayanan pasien.

\section{Kata Kunci $\quad$ : Perawat; Perilaku caring; Kepuasan; Pasien}

\section{PENDAHULUAN}

Kepuasan merupakan perasaan seseorang mengenai kesenangan atau kekecewaan sebagai hasil perbandingan antara kinerja dan harapan. Apabila kinerja yang diterima di bawah harapan mereka, maka pasien merasa tidak puas. Apabila kinerja sesuai atau melebihi harapan maka pasien akan merasa puas. Pengalaman jasa kesehatan sebelumnya penting untuk menentukan evaluasi penggunaan pelayanan kesehatan yang sama di masa yang akan datang. Pengalaman tersebut akan mempengaruhi harapan pasien untuk memperoleh pelayanan yang sama (Tjiptono, 2015).

Standar kepuasan pasien di pelayanan kesehatan ditetapkan secara nasional oleh Departemen Kesehatan. Menurut Peraturan Kementrian Kesehatan Republik Indonesia Tahun 2017 tentang Standar Pelayanan Minimal untuk kepuasan pasien yaitu diatas $95 \%$. Bila ditemukan pelayanan kesehatan dengan tingkat kepuasaan pasien berada dibawah 95\%, maka dianggap pelayanan kesehatan yang diberikan tidak memenuhi standar minimal atau tidak berkualitas (Kementerian Kesehatan Republik Indonesia, 2017).

Hubungan perawat - klien yang terbentuk diharapkan dapat memfasilitasi partisipasi klien dengan memotivasi keinginan klien untuk bertanggung jawab terhadap kondisi kesehatannya. Perilaku caring perawat diperlukan dalam membina hubungan yang harmonis antara perawat - klien. Caring dalam keperawatan menyangkut upaya memperlakukan klien secara manusiawi dan utuh sebagai manusia yang berbeda dari manusia lainnya (Departemen Kesehatan, 2012.). Hal ini berkaitan dengan proses yang humanis dalam menentukan kondisi terpenuhi tidaknya kebutuhan dasar manusia dan melakukan upaya pemenuhannya melalui berbagai bentuk intervensi yang bukan hanya berupa kemampuan teknis tetapi disertai "warmth, kindness, compassion" (Blais, 2009; Rahayu, 2012).

Hasil penelitian sebelumnya terdapat hubungan yang signifikan antara perilaku caring perawat dengan tingkat kepuasan dengan nilai $p$-value sebesar 0.026 Penelitian (Satrianegara, 2014; Hutapea, 2014). Hal ini didukung oleh penelitian Shirley, tentang tingkat kepuasan dibangsal orthopedi dengan kepedulian perawat di Rumah Sakit Universitas Sains Malaysia, didapatkan merasa puas dengan pelayanan perawat seperti menghargai pasien, tentang, lemah lembut, perhatian, kasih sayang dan empati. Hasil penelitian bahwa ada hubungan yang signifikan antara perilaku caring perawat dengan tingkat kepuasan rawat inap rumah sakit (Abdul, 2014).

\section{METODE PENELITIAN}

Jenis penelitian kuantitatif dengan populasinya pasien rawat jalan yang punya pengalaman dirawat pada waktu maksimal satu tahun yang lalu di Puskesmas tersebut dengan sampel sejumlah 282 responden dengan teknik accidental sampling, di UPT Puskesmas Rawat Inap Bukit Kemuning Kabupaten Lampung Utara.

Penelitian ini menggunakan alat ukur kuesioner caring dan kepuasan pasien dengan perawat, dengan jumlah soal 11 pertanyaan kuesioner caring dengan skor terendah 0 dan tertinggi 11 dan 13 pertanyaan kuesioner kepuasan dengan skor terendah 0 dan tertinggi 13 . Uji laik etik di universitas malahayati bandar lampung dengan nomor nomor: 0600.44.02.406.02.2020 tanggal 18 Februari 2019. 
HASIL

Tabel 1. Distribusi Frekuensi Karakteristik Responden $\mathrm{N}=\mathbf{2 8 2}$

\begin{tabular}{|c|c|c|c|}
\hline $\begin{array}{c}\text { Karakteristik Demografi } \\
\text { Responden }\end{array}$ & $\mathrm{n}$ & $\%$ & MISD \\
\hline Umur (Tahun) (Rentang: 22-55) & 282 & 100 & $31.35 \pm 3.00$ \\
\hline $\begin{array}{ll}\text { Jenis Kelamin: } \\
-\quad \text { Laki-laki } \\
-\quad \text { Perempuan }\end{array}$ & $\begin{array}{l}129 \\
153\end{array}$ & $\begin{array}{l}45.7 \\
54.3\end{array}$ & \\
\hline $\begin{array}{l}\text { Pendidikan } \\
-\quad \text { SMP } \\
-\quad \text { SMA }\end{array}$ & $\begin{array}{l}111 \\
171\end{array}$ & $\begin{array}{l}39.4 \\
60.6\end{array}$ & \\
\hline $\begin{array}{l}\text { Pernyataan Responden Tentang } \\
\text { Perilaku Caring Perawat } \\
\text { - Buruk } \\
\text { - } \text { Baik }\end{array}$ & $\begin{array}{l}162 \\
120\end{array}$ & $\begin{array}{l}57.4 \\
42.6\end{array}$ & \\
\hline $\begin{array}{l}\text { Tingkat Kepuasan Pasien } \\
-\quad \text { Kurang puas } \\
-\quad \text { Puas }\end{array}$ & $\begin{array}{l}140 \\
142\end{array}$ & $\begin{array}{l}49.6 \\
50.4\end{array}$ & \\
\hline
\end{tabular}

Berdasarkan tabel 1 diatas diketahui rata rata jenis kelamin perempuan dengan jumlah 153 responden $(54.3 \%)$ berusia 31 tahun dengan rata rata (mean) 31.35 tahun \pm 3.00 , Pendidikan responden SMA yaitu 171 (60.6\%). Sebagian responden mengatakan perilaku caring perawat buruk, yaitu sebesar 162 (57.4\%). Sedangkan tingkat kepuasan diketahui sebagian besar responden mengatakan puas sebanyak 142 (50.4\%).

Tabel 3. Hubungan Perilaku Caring Perawat Terhadap Tingkat Kepuasan Pasien N $=282$

\begin{tabular}{lcccccccc}
\hline $\begin{array}{l}\text { Perilaku } \\
\text { Caring }\end{array}$ & Kurang Puas & \multicolumn{2}{c}{ Puas } & N & $\%$ & $p$-value & OR \\
Perawat & $\mathbf{n}$ & $\%$ & $\mathbf{n}$ & $\%$ & & & & \\
\hline Buruk & 105 & 37.2 & 57 & 20.2 & 162 & 57.4 & 0.001 & 4.659 \\
Baik & 34 & 8.5 & 86 & 34.1 & 120 & 42.6 & & $(2.794-7.771)$ \\
\hline
\end{tabular}

Berdasarkan Tabel 3 dapat dilihat kategori perilaku caring yang buruk, dari $57.4 \%$ didapat sebanyak $105(37.2 \%)$ responden menyatakan kurang puas dan sebanyak $57(20.2 \%)$ responden menyatakan puas. Sedangkan dari 120 (42.6\%) responden yang mengatakan Perilaku caring perawt kategori baik, didapatkan sebanyak 34 $(8.5 \%)$ responden mengatakan kurang puas, dan $86(34.1 \%)$ responden mengatakan puas.
Hasil uji statistik diperoleh $p$-value $=0,001$ yang berarti $p<\alpha=0,05$ (Ho ditolak), maka dapat disimpulkan bahwa ada Hubungan perilaku caring perawat terhadap tingkat kepuasan pasien di UPT Puskesmas Rawat Inap Bukit Kemuning Kabupaten Lampung Utara tahun 2019. Dengan nilai OR 4,659 berarti perilaku caring perawat yang buruk memiliki resiko 4,7 kali lebih besar dimana pasien mengatakan kurang puas jika

Triyoso"* Program DIll Keperawatan Fakultas Kedokteran Universitas Malahayati. *Email: triyosoalip@gmail.com Martina Sari ${ }^{2}$ UPT Puskesmas Rawat Inap Bukit Kemuning Kabupaten Lampung Utara. Email:martinasaril983@gmail.com 
dibandingkan dengan perilaku caring perawat yang baik.

\section{PEMBAHASAN}

\section{Perilaku Caring Perawat}

Berdasarkan hasil penelitian diketahui sebagian besar responden mengatakan perilaku caring perawat baik, yaitu sebesar $120 \quad(42.6 \%)$ responden dan 162 (57.4\%) responden mengatakan perilaku caring perawat buruk. Penelitian ini sejalan dengan dengan teori Watson yang mengungkapkan bahwa perilaku caring perawat diperlukan dalam membina hubungan yang harmonis antara perawat - klien. Caring dalam keperawatan menyangkut upaya memperlakukan klien secara manusiawi dan utuh sebagai manusia yang berbeda dari manusia lainnya (Watson, 1980; Rahayu, 2012). Hal ini berkaitan dengan proses yang humanis dalam menentukan kondisi terpenuhi tidaknya kebutuhan dasar manusia dan melakukan upaya pemenuhannya melalui berbagai bentuk intervensi yang bukan hanya berupa kemampuan teknis tetapi disertai "warmth, kindness, compassion" (Carlo,Chow, Gambetta, Bishop, Johnson, Schuster, \& Schoelkopf, 2009; Rahayu, 2012).

Sejalan dengan penelitian yang berjudul hubungan perilaku caring perawat dengan tingkat kepuasan pasien rawat inap kelas III DI Bangsalah Marwah RS PKU Muhammadiyah Yogyakarta. Hasil penelitian responden yang menilai perilaku caring perawat dengan kategori selalu dilakukan yaitu 9 responden $(27,3 \%)$. Sedangkan responden yang paling banyak menilai perilaku caring perawat adalah dilakukan dengan jumlah 23 responden (69, 7\%) (Swastiyasa, 2018).

Hasil penelitian ini sejalan dengan penelitian menunjukan distribusi perilaku caring perawat menurut responden di Poli TB RS Paru Jember. Responden yang menilai perawat menunjukkan perilaku caring yaitu sebesar 18 orang $(56,3 \%)$ sedangkan responden yang menilai perawat menunjukkan perilaku tidak caring yaitu sebesar 14 orang $(43,7 \%)$. Data tersebut menunjukkan bahwa perawat di Poli TB RS Paru Jember mayoritas menunjukkan perilaku caring pada saat merawat pasien (Rahayu,2012). Begitu Pula dengan penelitian lain menunjukkan bahwa $81,3 \%$ responden mempunyai persepsi bahwa perawat mempunyai perilaku caring yang baik. Penelitian (Manimaran, Sindhya, Venkateshwaran.2010) menunjukan hasil bahwa sebagian besar responden mengungkapkan perilaku caring perawat baik sebanyak $15(53,3 \%)$ responden. Serta penelitian (Nurkatamso, \& Listianingsih (2012) menunjukan bahwa lebih dari setengahnya $(60,2 \%)$ atau 59 pasien false emergency menyatakan bahwa perilaku caring perawat adalah baik (Abdul, 2013).

Menurut pendapat peneliti, dari hasil penelitian diketahui sebagian besar responden mengatakan perilaku caring perawat baik, hal ini dimungkinkan karena keyakinan dan harapan pasien kepada perawat dapat terpenuhi seperti perawat memberikan semangat dalam menjalani pengobatan, memberi dukungan untuk kesembuhan, memanggil nama pasien dengan nama yang disenangi, menjelaskan penyakit yang dialami pasien sehingga pasien paham, perlakuanperlakuan seperti ini sehingga responden merasa bahwa perawat sudah memberikan sikap / perilaku caring yang baik, namun pada penelitian juga didapati bahwa sebagian responden mengungkapan bahwa perilaku caring perawat tidak baik hal ini mungkin dapat disebabkan karena perawat tidak segera datang saat pasien pemanggil, perawat tidak dapat memenuhi kebutuhan sehari-hari dari semua pasien yang ada seperti membantu makan, minum, melakukan personal hygiene dan terkadang perawat lupa untuk mengenalkan diri ke semua pasien yang ditemui di ruangan.

Menurut pendapat peneliti caring merupakan fenomena dari semua faktor yang digunakan perawat dalam memberikan pelayanan kesehatan pada klien, caring juga menekankan harga diri individu, artinya dalam melakukan praktik keperawatan, perawat senantiasa selalu menghargai klien dengan menerima kelebihan maupun kekurangan pasien. Dalam keperawatan, caring merupakan bagian inti yang penting terutama dalam praktik keperawatan dan diyakini berperilaku caring untuk klien dan bekerja bersama dengan klien dari berbagai lingkungan merupakan esensi keperawatan. caring merupakan praktik keperawatan dimana perawat membantu klien pulih dari sakitnya. Kehadiran, kontak mata, bahasa tubuh, nada suara, sikap mau mendengarkan serta memiliki sikap positif dan bersemangat yang dilakukan perawat kepada klien akan membentuk suasana keterbukaan dan saling mengerti, serta perlakuan yang ramah dan cekatan

Triyoso'Program DIIl Keperawatan Fakultas Kedokteran Universitas Malahayati. *Email: triyosoalip@gmail.com Martina Sari ${ }^{2}$ UPT Puskesmas Rawat Inap Bukit Kemuning Kabupaten Lampung Utara. Email:martinasaril983@gmail.com 
ketika melaksanakan prosedur keperawatan akan memberikan rasa aman pada klien. Semakin baik perilaku caring perawat dalam memberikan pelayanan asuhan keperawatan, pasien atau keluarga semakin senang dalam menerima pelayanan, berarti hubungan terapeutik perawatklien semakin terbina. responden merasa puas dengan perawat yang ramah, mudah senyum, sopan dan memberi perhatian.

\section{Tingkat Kepuasan Pasien}

Berdasarkan hasil penelitian sebagian besar responden mengatakan puas, yaitu sebesar 142 (50.4\%) responden dan sebanyak $140(49.6 \%)$ mengatakan kurang puas. Penelitian ini sejalan dengan teori yang yang disampaikan dimana kepuasan merupakan perasaan seseorang mengenai kesenangan atau kekecewaan sebagai hasil perbandingan antara kinerja dan harapan. Apabila kinerja yang diterima di bawah harapan mereka, maka pasien merasa tidak puas. Apabila kinerja sesuai atau melebihi harapan maka pasien akan merasa puas. Pengalaman jasa kesehatan sebelumnya penting untuk menentukan evaluasi penggunaan pelayanan kesehatan yang sama di masa yang akan datang. Pengalaman tersebut akan mempengaruhi harapan pasien untuk memperoleh pelayanan yang sama (Tjiptono, 2015). Terpenuhinya kebutuhan pasien akan mampu memberikan gambaran terhadap kepuasan pasien, oleh karena itu tingkat kepuasan pasien sangat tergantung pada persepsi atau harapan mereka pada pemberi jasa pelayanan. Kebutuhan pasien yang sering diharapkan adalah keamanan pelayanan, harga dalam memperoleh pelayanan, ketepatan dan kecepatan pelayanan kesehatan (Pohan, 2013 ; Azwar, 2016).

Sejalan dengan penelitian Sebelumnya Hasil penelitian tentang kepuasan ibu didapatkan bahwa sebagian besar ibu yaitu 22 responden $(81,5 \%)$ tingkat kepuasannya baik sedangkan sisanya 5 responden $(18,5 \%)$ tingkat kepuasannya sedang. Penelitian Rifai (2018) dengan judul Hubungan Perilaku Caring Perawat Dengan Kepuasan Pasien Di Ruang Rawat Inap Kelas III RSUD Dr. Loekmonohadi Kudus Hasil penelitian ini menunjukan bahwa prosentase terbesar perilaku caring perawat diruang rawat inap khususnya kelas III RSUD dr. Loekmonohadi kudus sebanyak $(66,1 \%)$ menyatakan puas $(32,2 \%)$ merasakan cukup puas dan $(1,7 \%)$ menyatakan tidak puas terhadap perilaku caring perawat.( Rahardja, Lutfiani, \& Rahmawati, 2018).

Menurut pendapat peneliti bahwa memahami kebutuhan dan keinginan konsumen dalam hal ini pasien adalah hal penting yang mempengaruhi kepuasan pasien. Pasien yang puas merupakan aset yang sangat berharga karena apabila pasien puas mereka akan terus melakukan pemakaian terhadap jasa pilihannya, tetapi jika pasien merasa tidak puas mereka akan memberitahukan dua kali lebih hebat kepada orang lain tentang pengalaman buruknya. Menurut pendapat peneliti dengan hasil penelitian sebagian besar responden mengatakan puas, hal ini dimungkinkan karena penanganan perawat yang cepat, perawat perhatian terhadap pasien, perawat melakukan komunikasi dan perawat berpenampilan rapi sehingga pasien / responden menunjukkan kepuasannya dan terdapat responden tidak puas hal ini dimungkinkan karena kemungkinan disaat pasien memerlukan perawat, namun perawat masih disibukkan dengan kegiatan dengan pasien lain, perawat terlihat buru-buru dalam menangani pasien, dan pasien merasa perawat tidak perhatian terhadap dirinya.

Menurut pendapat peneliti masih ada perawat yang menjunjung tinggi tentang pelayanan kepada pasien tanpa membedakan jenis penyakit yang diderita oleh pasien, selain itu adanya pemantauan manajemen secara langsung kepada perawat dan adanya reward yang akan diberikan kepada perawat jika perawat menunjukkan kinerja yang baik kepada pasien. Memahami kebutuhan dan keinginan pasien adalah hal penting karena dapat mempengaruhi kepuasan pasien. Pasien yang puas merupakan aset yang sangat berharga karena apabila pasien puas mereka akan terus melakukan pemakaian terhadap jasa pilihannya, tetapi jika pasien merasa tidak puas mereka akan memberitahukan dua kali lebih hebat kepada orang lain tentang pengalaman buruknya. Untuk menciptakan kepuasan pasien harus menciptakan dan mengelola suatu sistem untuk memperoleh pasien yang lebih banyak dan kemampuan untuk mempertahankan pasiennya.

\section{Hubungan perilaku caring perawat terhadap tingkat kepuasan pasien \\ Hasil uji statistik diperoleh $p$-value $=0,000$ yang berarti $p<a=0,05$ (Ho ditolak dan Ha diterima), maka dapat disimpulkan bahwa ada Hubungan}

Triyoso ${ }^{1 *}$ Program DIII Keperawatan Fakultas Kedokteran Universitas Malahayati. *Email: triyosoalip@gmail.com Martina Sari ${ }^{2}$ UPT Puskesmas Rawat Inap Bukit Kemuning Kabupaten Lampung Utara. Email:martinasari1983@gmail.com 
perilaku caring perawat terhadap tingkat kepuasan pasien di UPT Puskesmas Rawat Inap Bukit Kemuning Kabupaten Lampung Utara tahun 2019. Dengan nilai OR 4,659 berarti perilaku caring perawat yang baik akan meningkatkan kepuasan pasien dan pasien sebanyak 4,659 kali.

Penelitian ini sejalan dengan teori caring perawat merupakan sikap peduli yang memudahkan pasien untuk mencapai peningkatan kesehatan dan pemulihan. Perilaku caring sebagai bentuk peduli, memberikan perhatian kepada orang lain, berpusat pada orang, menghormati harga diri, dan kemanusiaan, komitmen untuk mencegah terjadinya status kesehatan yang memburuk, memberi perhatian dan menghormati orang lain (Nursalam, 2014). Mutu pelayanan kesehatan merupakan kesempurnaan suatu produk dalam pelayanan kesehatan yang dapat memuaskan setiap pemakai jasa. Pelayanan yang bermutu merupakan penyelenggaraan pelayanan yang diberikan sesuai dengan prosedur dan standar pada kode etik profesi yang telah ditetapkan, dengan menyesuaikan potensi dari sumber daya yang tersedia secara aman dan memuaskan yang dilakukan dengan wajar, efisien dan efektif dengan memperhatikan keterbatasan dan kemampuan pemerintah dan masyarakat konsumen (Methagagarin, 2012; Azwar, 2016).

Memberikan asuhan (Caring) secara sederhana tidak hanya sebuah perasaan emosional atau tingkah laku sederhana, karena caring merupakan kepedulian untuk mencapai perawatan yang lebih baik, perilaku caring bertujuan dan berfungsi membangun struktur sosial, pandangan hidup dan nilai kultur setiap orang yg berbeda pada satu tempat, maka kinerja perawat khususnya pada perilaku caring menjadi sangat penting dalam mempengaruhi kualitas pelayanan dan kepuasan pasien terutama di rumah sakit, dimana kualitas pelayanan menjadi penentu citra institusi pelayanan yang nantinya akan dapat meningkatkan kepuasan pasien dan mutu pelayanan (Potter, \& Perry, 2013).

Memberikan perhatian yang tulus kepada pasien yang bersifat individual atau pribadi yang berupaya dalam memahami keinginan pasien. Pelayanan yang diberikan berupa perawat meluangkan waktu khusus sehingga terjadi hubungan perawat-pasien untuk berkomunikasi, menghibur dan memberi dorongan kepada pasien, ada waktu berkonsultasi dengan perawat, dan perawat perhatian akan keamanan barang berharga pasien (Asmuji, 2013).

Sejalan dengan penelitian Sebelumnya Hasil penelitian menunjukkan ada hubungan yang signifikan antara perilaku caring perawat dengan kepuasan pasien jiwa di IRJ RSJD Provinsi Lampung Tahun 2014 ( p-Value 0,005) (Mailani, \& Fitri, 2017 ).

Menurut pendapat peneliti terhadap responden yang menyatakan perilaku caring baik dan menyatakan tidak puas hal ini dimungkinkan terjadi dimana seorang pasien yang pada masa sehat terbiasa hidup dengan pelayanan yang sepenuhnya dipusatkan pada pemuasan semua keinginan, tentu sewaktu mendapat perawatan akan menuntut perlakuan yang sesuai dengan yang diperolehnya dalam hidup sehari-hari sehingga dengan indikator yang berbeda pada setiap orang maka kepuasan yang dirasakan pun berbeda. ada orang sakit yang ingin selalu diperhatikan dan menarik perhatian perawat, ada pula pasien yang sungkan dan segan untuk memanggil dan meminta bantuan perawat.

Adanya faktor lain yang mempengaruhi kepuasan pada pasien yang tidak diambil dalam penelitian ini, sehingga walaupun perilaku caring sudah baik namun tetap pasien tidak merasa puas,fenomena ini dapat diatasi dengan melakukan kajian kepada pasien yang tidak merasa puas untuk menelaah lebih lanjut penyebab ketidakpuasan yang terjadi sehingga puskesmas dapat mengevaluasi mutu layanan yang diberikan dengan tujuan meningkatkan kualitas layanan rumah sakit. dan dari responden yang mengungkapkan perilaku caring tidak baik, terdapat responden menyatakan puas, hal ini dimungkinkan oleh cara perawat dalam hubungannya dengan pasien/ . perawat yang dapat meyakinkan pasien/ akan memperoleh kepercayaan dari pasien, sehingga secara tidak langsung dapat membantu membentuk sikap positif pasien terhadap perawat.

Menciptakan sebuah kepercayaan pasien kepada perawat adalah dengan menciptakan waktu bersama perawat dan pasien. Perawat yang berhasil adalah membangun kepercayaan akan membuat pekerjaan perawat menjadi lebih mudah karena pasien yang sudah percaya akan menerima seluruh kegiatan yang dilakukan oleh perawat dalam memberikan pelayanan asuhan keperawatan untuk kepuasan pasien. 
Semakin baik perilaku caring perawat dalam memberikan pelayanan asuhan keperawatan, pasien atau semakin senang dalam menerima pelayanan, berarti hubungan terapeutik perawatklien semakin terbina.

Berdasarkan hasil kuesioner dengan, responden ditemukan bahwa merasa puas dengan perawat yang ramah, mudah senyum, sopan dan memberi perhatian. Pernyataan responden tersebut sesuai dengan teori yang mengatakan bahwa caring merupakan praktik keperawatan dimana perawat membantu klien pulih dari sakitnya. Kehadiran, kontak mata, bahasa tubuh, nada suara, sikap mau mendengarkan serta memiliki sikap positif dan bersemangat yang dilakukan perawat kepada klien akan membentuk suasana keterbukaan dan saling mengerti, serta perlakuan yang ramah dan cekatan ketika melaksanakan prosedur keperawatan akan memberikan rasa aman pada klien.

\section{SIMPULAN}

Diketahui perilaku caring perawat di UPT Puskesmas Rawat Inap Bukit Kemuning Kabupaten Lampung Utara sebagian besar responden mengatakan perilaku caring perawat kurang baik, yaitu sebesar $162(57.4 \%)$, dan 120 (42.6) responden mengatakan perilaku caring perawat baik.

Diketahui tingkat kepuasan pasien di UPT Puskesmas Rawat Inap Bukit Kemuning Kabupaten Lampung Utara sebagian besar sebanyak $142(50.4 \%)$ responden menyatakan puas dan sebanyak 140 (49.4\%) responden mengatakan kurang puas.

Didapatkan hubungan antara perilaku caring perawat terhadap tingkat kepuasan pasien di UPT Puskesmas Rawat Inap Bukit Kemuning Kabupaten Lampung Utara tahun 2019 (pvalue $=0,000$ OR=4.659)

\section{SARAN}

Bagi perawat supaya lebih berhati-hati dalam melakukan tindakan agar kepuasan klien dan juga standarisasi instansi pekerjaan terjaga. Bagi pihak manajemen Puskesmas sebagai bahan pertimbangan untuk mengadakan pelatihan perilaku caring perawatguna meningkatkan pelayanan pasien.

\section{DAFTAR PUSTAKA}

Abdul, A. S., \& Sjattar, E. L. (2014). Hubungan Perilaku Caring Perawat dengan Tingkat Kepuasan Pasien Rawat Inap Rumah Sakit. Jurnal IImu Keperawatan. Universitas Hasanudin.

Asmuji, A. (2019). Faktor-faktor yang berhubungan dengan kapasistas kerja terhadap perilaku caring perawat di RSD balung. In prosiding seminar nasional 2018 "Peran Dan Tanggung Jawab Tenaga Kesehatan Dalam Mendukung Program Kesehatan Nasional"(pp. 257-264).

Azwar, S. (2016). Konstruksi tes kemampuan kognitif. Yogyakarta: Pustaka Pelajar.

DiCarlo, L., Chow, J. M., Gambetta, J. M., Bishop, L. S., Johnson, B. R., Schuster, D. I., \& Schoelkopf, R. J. (2009). Demonstration of twoqubit algorithms with a superconducting quantum processor. Nature, 460(7252), 240.

Hutapea, K. A., Dedi, B., \& Elias, Y. (2014). Hubungan Perilaku Caring Perawat Dengan Tingkat Kepuasan Pasien yang dirawat di Ruangan Kelas III Rumah Sakit Immanuel Bandung. Jurnal IImu KesehatanSekolah Tinggi IImu Kesehatan Immanuel Bandung, 8(2).

Kementerian Kesehatan Republik Indonesia. (2017). pusat data dan informasi Profil Kesehatan Indonesia 2016. Kementerian Kesehatan RI, Jakarta.

Mailani, F., \& Fitri, N. (2017). Hubungan perilaku caring perawat dengan tingkat kepuasan pasien BPJS di ruang rawat inap RSUD $\mathrm{dr}$. Rasidin padang. Jurnal Endurance: Kajian IImiah Problema Kesehatan, 2(2), 203-208.

Manimaran, S., Sindhya, R., \& Venkateshwaran, P. S. (2010). A study of patients expectation and satisfaction in dindigul hospitals. Asian Journal of Management Research, 1(1), 31-43.

Triyoso ${ }^{1 *}$ Program DIII Keperawatan Fakultas Kedokteran Universitas Malahayati. *Email: triyosoalip@gmail.com Martina Sari ${ }^{2}$ UPT Puskesmas Rawat Inap Bukit Kemuning Kabupaten Lampung Utara. Email:martinasari1983@gmail.com 
Perilaku caring perawat terhadap kepuasan pasien di UPT Puskesmas rawat inap

Nurkatamso, A., \& Listyaningsih, U. (2013). Tingkat partisipasi masyarakat dalam program fisik program nasional pemberdayaan masyarakat mandiri pedesaan di Kecamatan Nanggulan Kabupaten Kulonprogo, Yogyakarta. Jurnal Bumi Indonesia, 2(2).

Nursalam, M. (2014). Manajemen Keperawatan. Jakarta: Salemba Medika.

Pohan, I. S. (2007). Jaminan mutu layanan kesehatan: dasar-dasar pengertian dan penerapan. Jakarta: EGC.

Prihandhani, I. G. A. S., Nopiyani, N. S., \& Duarsa, D. P. (2015). Hubungan Faktor Individu dan Budaya Organisasi dengan Perilaku Caring Perawat Pelaksana di Ruang Rawat Inap Rumah Sakit Umum Ganesha Gianyar. Public Health and Preventive Medicine Archive.
Tjiptono, F., \& Diana, A. (2015). Pelanggan puas. Tak Cukup.

Rahardja, U., Lutfiani, N., \& Rahmawati, R. (2018). Persepsi Mahasiswa Terhadap Berita Pada Website APTISI. Sisfotenika, 8(2), 117-127.

Satrianegara, F. (2014). Organisasi dan Manajemen Pelayanan Kesehatan. Jakarta: Salemba Medika

Watson, G. (1980). Watson-Glaser critical thinking appraisal. San Antonio, TX: Psychological Corporation.

Wiratama, W. J., \& Budiartha, K. (2015). Pengaruh Independensi, Pengalaman Kerja, Due Professional Care dan Akuntabilitas Terhadap Kualitas Audit. E-Jurnal Akuntansi Universitas Udayana, 10(1), 91-106.

Triyoso ${ }^{1 *}$ Program DIII Keperawatan Fakultas Kedokteran Universitas Malahayati. *Email: triyosoalip@gmail.com Martina Sari ${ }^{2}$ UPT Puskesmas Rawat Inap Bukit Kemuning Kabupaten Lampung Utara. Email:martinasaril983@gmail.com 